\title{
Organic matter seasonality and ecosystem metabolism in two tropical first-order streams
}

\author{
Daniela Cortés Guzmán ${ }^{1}$ (D), Javier Alcocer ${ }^{2, *}$ (D), José Daniel Cuevas Lara ${ }^{1}$ (D), Ismael Soria \\ Reinoso $^{1}$ (D), Luis A. Oseguera² (D) and Martín Merino-Ibarra ${ }^{3}$
}

${ }^{1}$ Programa de Posgrado en Ciencias del Mar y Limnología, Universidad Nacional Autónoma de México, Av. Universidad 3000, Ciudad de México 04510, México.

2 Grupo de Investigación en Limnología Tropical, FES Iztacala, Universidad Nacional Autónoma de México, Av. de los Barrios 1, Estado de México 54090, México.

3 Unidad Académica de Ecología y Biodiversidad Acuática, Instituto de Ciencias del Mar y Limnología, Universidad Nacional Autónoma de México, Av. Universidad 3000, Ciudad de México 04510, México.

* Corresponding author: jalcocer@unam.mx

Received: $13 / 03 / 21 \quad$ Accepted: 21/07/21

\begin{abstract}
Organic matter seasonality and ecosystem metabolism in two tropical first-order streams

Dissolved and particulate organic matter are the energy source for secondary production in forested streams. Cycling of organic matter and stream ecosystem functioning are linked to organic matter input and storage capacity and timing. This study assessed the seasonal variation (dry and rainy seasons) of environmental parameters, organic matter stock and input, and stream metabolism in two first-order tropical streams in the Selva Lacandona, Mexico. We also aimed to identify the drivers of organic matter and stream metabolism seasonality. We found seasonal variation in organic matter stock and input correlated with tropical seasonality. Dissolved organic matter and seston increased in the rainy season, while benthic primary producers and leaf litter stock and input increased in the dry season correlated with lower water discharge. Gross primary production increased in the dry season, while ecosystem respiration did not differ between seasons. Seasonality defined by the rainfall pattern and its effect on stream hydrology is the main driver of organic matter dynamics in tropical streams. However, environmental parameters and organic matter stock and input were not good predictors of stream metabolism.
\end{abstract}

Key words: particulate organic matter, dissolved organic matter, standing stocks, organic matter inputs, Lacandona rainforest, Mexico

\section{RESUMEN}

Estacionalidad de la materia orgánica y el metabolismo ecosistémico en dos arroyos tropicales de primer orden

La materia orgánica, tanto particulada como disuelta, es la fuente de energía principal para la producción secundaria en arroyos de zonas boscosas. El reciclaje de la materia orgánica y el funcionamiento de los ecosistemas lóticos están asociados con la magnitud y estacionalidad de la acumulación y los aportes de materia orgánica. El objetivo de este estudio fue evaluar la variación estacional (temporadas de secas y lluvias) de los parámetros ambientales, la acumulación y aportes de materia orgánica y el metabolismo ecosistémico en dos arroyos tropicales de primer orden, en la Selva Lacandona, México. Asimismo, se buscó identificar los factores que controlan esta estacionalidad. Se encontró que la variabilidad en la acumulación y aportes de materia orgánica se correlacionaron con la estacionalidad tropical. La materia orgánica disuelta y el seston aumentaron en la temporada de lluvias, mientras que los productores primarios bentónicos y los aportes y cantidad de hojarasca aumentaron en la temporada de secas, correlacionado con la disminución del caudal. La producción primaria bruta incrementó en la temporada de secas, mientras que la respiración ecosistémica no difirió. La estacionalidad definida por el patrón de lluvias y su efecto en la hidrología de los arroyos son los principales factores que controlan la dinámica de la materia orgánica en arroyos tropicales. Sin embargo, los parámetros ambientales y la acumulación y aportes de materia orgánica no fueron buenos predictores del metabolismo ecosistémico. 
Palabras clave: materia orgánica particulada, materia orgánica disuelta, acumulación de materia orgánica, aportes de materia orgánica, Selva Lacandona, México

This is an open-access article distributed under the terms of the Creative Commons Attribution-NonCommercial 4.0 International (CC BY-NC 4.0) License.

\section{INTRODUCTION}

Low-order streams represent the most significant proportion of rivers' length and drain ample landscape areas (Benson \& Pearson, 2020). More importantly, they significantly contribute to organic matter processing due to the large amounts of materials they receive and their high retentive capacity (Tonin et al., 2017). Dissolved and particulate organic matter is the energy source for secondary production in stream food webs (Tonin et al., 2017). Particulate organic matter stocks also contribute to channel stability, reduce erosion, increase retentiveness, and serve as a habitat for organisms (Molinero, 2019; Tonin et al., 2017; Wetzel, 2001).

In forested tropical streams, organic matter stock and input vary temporally related to multiple factors, and their seasonal patterns are difficult to predict (Rios Touma et al., 2009). Allochthonous leaf litter input depends on rainfall (Tonin et al., 2017), phenology and composition of the riparian forest, bank slopes, litter humidity, overland flow and wind (Bambi et al., 2017; Carvalho \& Uieda, 2010; Molinero, 2019; Tonin et al., 2017). Macrophytes and benthic algae are controlled by light availability, rainfall, and stream hydrology, i.e., low and high flow seasons (Davies et al., 2008; Douglas et al., 2005). Dissolved and suspended organic matter usually increased in the high flow periods, but their quantity, quality, and timing depend on the link between the headwater production, downstream reaches and riparian forest (Minshall et al., 2000; Richardson et al., 2009; Vannote et al., 1980).

Ecosystem metabolism is an integrated measure of organic matter production and consumption (Demars et al., 2015; Odum, 1956). Several factors at different scales control ecosystem metabolism, including hydrology, climate, light availability, temperature, nutrient concentration, organic matter supply, canopy cover, stream ori- entation and substrate (Garcia et al., 2015; Ortiz-Zayas et al., 2005; Tank et al., 2010). At a local scale, organic matter is a proximal factor driving ecosystem metabolism (Gawne et al., 2007; Ortiz-Zayas et al., 2005; Staehr et al., 2012). However, this relationship is less studied than the relationship between metabolism and light availability or nutrient concentrations (e.g., Bernot et al., 2010; Garcia et al., 2015; Saltarelli et al., 2018). The role of proximal and distal factors driving metabolism has been primarily evaluated in temperate streams (e.g., Bernot et al., 2010; Fuß et al., 2017). Tropical streams are expected to differ in their metabolism from temperate streams because of their higher temperatures and higher and constant irradiance (Ortiz-Zayas et al., 2005). Studies in tropical streams have evaluated the role of nutrients, light and land-use changes in metabolism (Gücker et al., 2009; Saltarelli et al., 2018), but none have assessed organic matter seasonality in stream metabolism.

The present study aims to assess the seasonal variation of the organic matter stock and input in two tropical first-order streams and its role as a driver of ecosystem metabolism. We addressed the following specific objectives: 1) to assess the seasonal (rainy season vs. dry season) variation in environmental conditions, organic matter stocks and inputs (dissolved organic matter - DOMseston, leaf litter, and benthic primary producers), and ecosystem metabolism; 2) to identify environmental drivers of organic matter and metabolism seasonality; 3 ) to assess the role of organic matter stocks and inputs as drivers of ecosystem metabolic rates. We hypothesized that: 1) organic matter abundance correlates with stream seasonality, i.e., dry and rainy seasons. Benthic primary producers and leaf litter stock increase in the dry season correlated with the decrease in water discharge and turbidity. DOM, seston, and leaf litter inputs increase in the rainy season correlated with high-intensity rainfall and water runoff. 2) Stream 
metabolism, i.e., gross primary production (GPP) and ecosystem respiration (ER) reflect changes in organic matter seasonality. GPP correlates with the abundance of benthic primary producers in the dry season, while ER reflects changes in leaf litter stock increasing in the dry season.

\section{MATERIALS AND METHODS}

\section{Study site}

This study was performed in two first-order streams, José and Mario, tributaries of the Lacantún River in the Lacandona rainforest, Chiapas, Mexico (Fig. 1). The Lacantún River subbasin belongs to the hydrological region $\mathrm{N}^{\circ} 30$ Grijalva-Usumacinta, the most extensive river system in Mexico (Muñoz-Salinas \& Castillo, 2013). The subbasin covers $12526 \mathrm{~km}^{2}$ and has an elevation of $200 \mathrm{~m}$ a.s.l. Geological formations are mainly limestones, and the most common soils are lithosols, which have low organic matter content and are prone to weathering (Saavedra Guerrero et al., 2015).

The climate in the region is warm and rainy, with mean annual temperature of $27^{\circ} \mathrm{C}$ and mean annual rainfall of $3190 \mathrm{~mm}$ (García, 2004). The rainfall pattern mainly defines seasonality (Fig. 2).
The rainy season lasts from May to October, with two peaks in June and October. Average rainfall per month ranges between 96.4 and $338.0 \mathrm{~mm}$, mean monthly temperature between 23.2 and $25.7{ }^{\circ} \mathrm{C}$, mean solar radiation between 253 and $310 \mathrm{~W} / \mathrm{m}^{2}$, and mean wind speed between 2.3 and $3.2 \mathrm{~km} / \mathrm{h}$. The dry season lasts from November to May, with a small rainfall peak in February. Average rainfall per month ranges between 26.8 and $116.4 \mathrm{~mm}$, mean monthly temperature between 19.2 and $23.2^{\circ} \mathrm{C}$, mean solar radiation between 214 and $339 \mathrm{~W} / \mathrm{m}^{2}$, and mean wind speed between 2.3 and $18.1 \mathrm{~km} / \mathrm{h}$ (Servicio Meteorológico Nacional, "Montes Azules" weather station, $16^{\circ}$ $48^{\prime} 43$ " N, 913 31'29” W, $625 \mathrm{~m}$ a.s.1.).

The dominant vegetation in the region is the tropical evergreen rainforest, a diverse ecosystem with more than 267 species per hectare (Saavedra Guerrero et al., 2015). The tree species dominating the riparian zones are Ampelocera hottlei (Ulmaceae), Croton schiedeanus (Euphorbiaceae), and Protium copal (Burseraceae; Meli et al., 2015).

Streams in the Lacantún River subbasin are warm, low-mineralized, neutral, well-oxygenated and with low quantities of suspended solids (Álvarez-Porebski et al., 2015). José and Mario are $7.1 \mathrm{~km}$ apart from each other. The José stream $\left(16^{\circ} 6^{\prime} 50^{\prime} \mathrm{N}, 90^{\circ} 56^{\prime} 10^{\prime} \mathrm{W}\right)$ is surrounded by

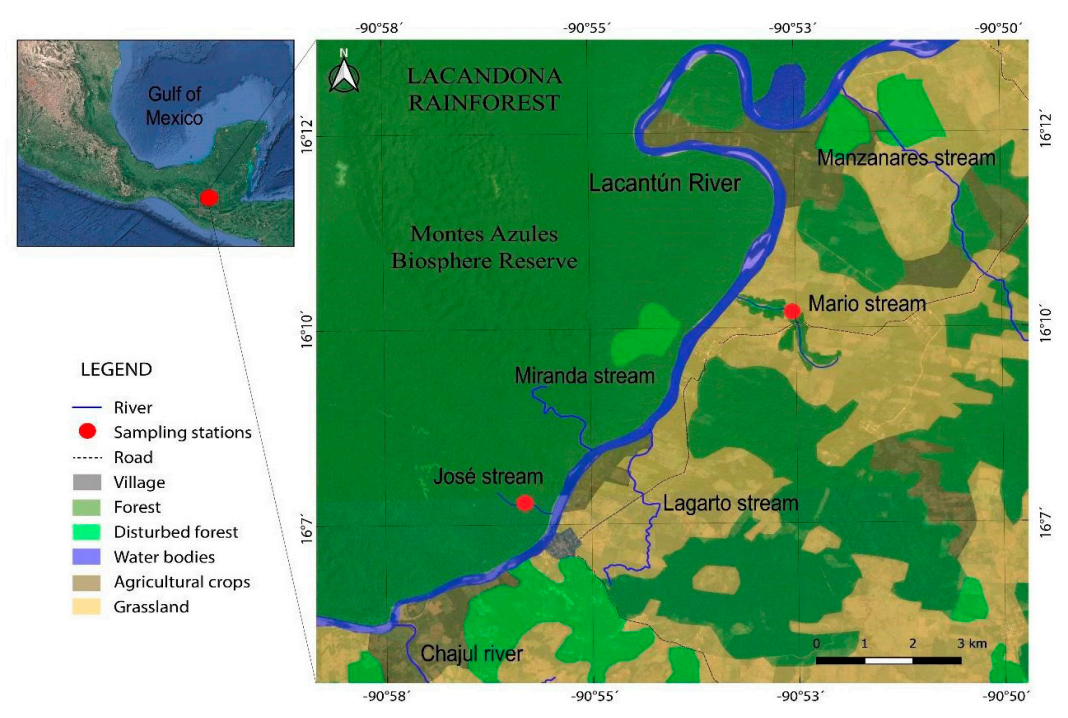

Figure 1. Location of the José and Mario streams. Ubicación de los arroyos José y Mario. 


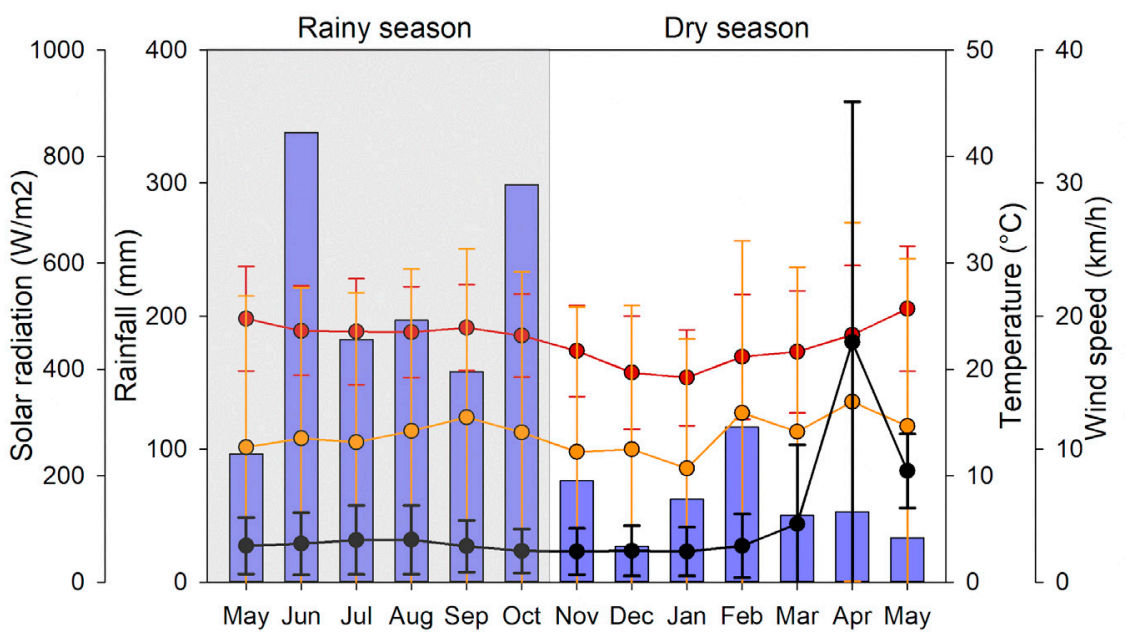

Figure 2. Mean ( \pm standard deviation) monthly temperature (red line), wind speed (black line), solar radiation (orange line) and accumulated monthly rainfall (blue bars) during the study period (May 2018- May 2019). Data from the "Montes Azules" weather station. Promedio ( \pm desviación estándar) mensual de temperatura (línea roja), rapidez del viento (línea negra), radiación solar (línea naranja) y precipitación mensual acumulada (barras azules) durante el periodo de estudio (mayo 2018- mayo 2019). Datos de la estación meteorológica "Montes Azules".

rainforest, $92 \%$ shaded and well-preserved. The Mario stream $\left(16^{\circ} 8,10^{\prime} \mathrm{N}, 90^{\circ} 54^{\prime} 27^{\prime}\right.$ W) is surrounded by rainforest in approximately $80 \%$ of its length, $78 \%$ shaded and showed minor disturbance degree (pasture-land use).

\section{Environmental variables}

The streams were sampled bi-monthly: three times in the rainy season (June, September, and October 2018) and three times in the dry season (January, March, and May 2019). We selected a $100 \mathrm{~m}$ long segment in each stream that included ponds, riffles, and various substrate types. The coverage of the different substrates along the $100 \mathrm{~m}$ segments was estimated using a $1 \mathrm{~m}^{2}$ frame. Substrate types were gravel-boulders $(2.1-64.0 \mathrm{~mm})$, sand $(0.05-2.0 \mathrm{~mm})$, and silt $(0.002-0.04 \mathrm{~mm})$. We measured the morphometric (width and depth), physical, and chemical variables at three points $(1 / 4,1 / 2$, and $3 / 4$ of the stream width) every $20 \mathrm{~m}$ in the $100 \mathrm{~m}$ segments. The water velocity was measured using a Swoffer 3000 current meter at half the maximum depth at each point. The water discharge was calculated by multiplying the water velocity by the stream cross-section area.
A multiparameter water quality probe (Hydrolab DS5) was used to measure water temperature, dissolved oxygen, $\mathrm{pH}$, conductivity and turbidity.

Water samples were collected for chlorophyll- $a$ and nutrient concentrations. First, we passed the water sample through a $100 \mu \mathrm{m}$ filter to remove larger particles. Chlorophyll- $a$ concentration in water followed the EPA 445.0 method (Arar \& Collins, 1997). Between 40 and $100 \mathrm{ml}$ of the sample were filtered through a glass fiber filter $(\mathrm{GF} / \mathrm{F} ; 0.7 \mu \mathrm{m})$. The chlorophyll- $a$ was extracted with acetone (90\%) for 24 hours and stored in dark and cold. We measured the chlorophyll- $a$ concentration with a digital fluorometer Turner Designs 10-AU. Nutrients were analyzed in a segmented flow autoanalyzer Skalar San Plus System. Total dissolved nitrogen and phosphorus were determined through oxidation at high pressure and high temperature with potassium persulfate (Valderrama, 1981). We followed Pujo-Pay \& Raimbault (1994) to determine nitrogen and phosphorus particulate organic fractions. $60 \mathrm{ml}$ of water were filtered through nitrocellulose filterers $(0.22$ and $0.45 \mu \mathrm{m})$ to measure ammonium and nitrate concentration (Kirkwood, 1994; Strickland \& Parsons, 1972). 


\section{Dissolved organic matter (DOM) input}

DOM was measured as dissolved organic carbon (DOC) concentration. We took a water sample and filtered it through a $100 \mu \mathrm{m}$ filter to remove larger particles. Then, we filtered three replicates of $40 \mathrm{ml}$ samples through a GF/F filter previously combusted $\left(550^{\circ} \mathrm{C}, 4 \mathrm{~h}\right)$ and preserved with $40 \%$ $\mathrm{H}_{3} \mathrm{PO}_{4}$. Finally, samples were analyzed in a Shimadzu TOC-L analyzer.

\section{Particulate organic matter (POM) input}

We quantified POM inputs as seston, direct litterfall, lateral leaf litter input (Bambi et al., 2017; Colón-Gaud et al., 2008), and transported leaf litter input from upstream (drift) (Pozo et al., 2009; Carvalho \& Uieda, 2010) at each stream. Seston includes all the organic and inorganic suspended materials, and it could be used as a proxy of fine particulate organic matter in transport (Hutchens et al., 2017). We used between 250 and $1200 \mathrm{ml}$ of pre-filtered $(100 \mu \mathrm{m})$ water. Samples were filtered again through $\mathrm{GF} / \mathrm{F}$ previously combusted $\left(550{ }^{\circ} \mathrm{C}, 4 \mathrm{~h}\right)$ and weighed. Then, we acidified filters with $\mathrm{HCl} 10 \%$ to eliminate the inorganic carbon (Seyler et al., 2005). Finally, the filters were dried $\left(60{ }^{\circ} \mathrm{C}, 48 \mathrm{~h}\right)$ and weighed again. Seston was analyzed by triplicate. Direct litterfall was quantified using six $0.045 \mathrm{~m}^{2}$ frames attached with a $1 \mathrm{~mm}$ mesh size screen. We distributed the traps throughout the $100 \mathrm{~m}$ segments and installed them above and perpendicularly to the channel, supported by synthetic ropes tied to trees. Lateral inputs were measured with another six frames with the same characteristics as those for the direct litterfall. We installed the traps along the stream banks in areas with a gentle slope down to the streams. Transported inputs were measured using drift nets $\left(0.4 \mathrm{~m}^{2}\right)$ of $1 \mathrm{~mm}$ mesh size. We installed three drift nets in the upper section of the $100 \mathrm{~m}$ segment and left them for 1 hour.

Materials from direct and lateral traps were collected every two months and stored in the cold to further analysis in the laboratory. Materials were dried $\left(60{ }^{\circ} \mathrm{C}, 48 \mathrm{~h}\right)$, weighed, combusted $\left(550{ }^{\circ} \mathrm{C}, 4 \mathrm{~h}\right)$, and weighed again to obtain the ash-free dry mass (AFDM). To express the inputs in the same units (g AFDM m-2 $\mathrm{d}^{-1}$ ), we applied the equations from Pozo et al. (2009). We divided the AFDM into the traps sampling area and the time between sample dates for direct inputs. For lateral inputs, we divided the AFDM into the trap width and the time between sample dates; then, we multiplied the result by two and divided it by the mean width of the channel to express the results per area of the river channel. To calculate transported inputs, we divided the AFDM into the amount of water passing through the drift net (water velocity $x$ area of drift net submerged), then multiplied it by the water discharge, and the time elapsed divided it into the cross-channel section.

\section{POM standing stock}

We classified the POM standing stock into two categories: a) benthic primary producers, including the benthic algae and macrophytes, and b) the coarse particulate organic matter, composed mainly by leaf litter. We estimated the total coverage as the percentage of the substrate covered by each one along the $100 \mathrm{~m}$ segments using a $1 \mathrm{~m}^{2}$ frame. Six aleatory replicates of leaf litter samples were manually sampled using a $0.13 \mathrm{~m}^{2}$ frame. Three aleatory replicates of benthic algae were collected by scraping the surface of rocks; we then registered the rock area covered by the algae. Three aleatory replicates of macrophytes samples were manually sampled using a $0.13 \mathrm{~m}^{2}$ frame. Benthic primary producers were determined to genus level and confirmed by experts. Samples of benthic primary producers and leaf litter were dried $\left(60^{\circ} \mathrm{C}\right.$, $48 \mathrm{~h})$, weighed, combusted $\left(550{ }^{\circ} \mathrm{C}, 4 \mathrm{~h}\right)$ and weighed again to obtain the AFDM.

\section{Stream metabolism}

We employed the open diel oxygen method in a single station to measure the ecosystem metabolism (Demars et al., 2015; Odum, 1956) with a Hobo U26 oxygen probe coupled with a thermistor (dissolved oxygen resolution: $0.02 \mathrm{mg} / \mathrm{L}$, accuracy $\pm 0.2 \mathrm{mg} / \mathrm{L}$ up to $8 \mathrm{mg} / \mathrm{L} ; \pm 0.5 \mathrm{mg} / \mathrm{L}$ from 8 to $20 \mathrm{mg} / \mathrm{L}$; temperature resolution $0.02{ }^{\circ} \mathrm{C}$, accuracy $0.2^{\circ} \mathrm{C}$ ). The probe was installed submerged at $0.5 \mathrm{~m}(\approx$ half the mean depth) and left for 24-hour cycles. Dissolved oxygen and temperature readings were recorded every 5 minutes. 
Logistic problems prevented measuring in January 2019.

We applied the equations from Grace \& Imberger (2006) to calculate the gross primary production (GPP) and ecosystem respiration (ER) from the dissolved oxygen (DO) measurements. For each time measurement, we calculated the following variables:

The $100 \%$ DO saturation at any temperature ( $\mathrm{T}$ in Kelvin):

$$
\begin{aligned}
\ln (100 \% D O)= & -139.34411+\frac{1.575701 * 10^{5}}{T}-\frac{6.642308 * 10^{7}}{T^{2}} \\
& +\frac{1.2438 * 10^{10}}{T^{3}}-\frac{8.621949 * 10^{11}}{T^{4}}
\end{aligned}
$$

The DO deficit (D):

$$
D=100 \% \mathrm{DO}\left(\mathrm{mg} \mathrm{O}_{2} L^{-1}\right)-\text { measured } \mathrm{DO}\left(\mathrm{mg} \mathrm{O}_{2} \mathrm{~L}^{-1}\right)
$$

The reaeration coefficient $\left(\mathrm{K}_{\mathrm{O} 2}\right)$ standardized at $20{ }^{\circ} \mathrm{C}$ :

$$
K_{O 2\left(20^{\circ} \mathrm{C}\right)}=50.8\left(\text { water velocity }\left(\mathrm{cm} / \mathrm{s}^{-1}\right)^{0.67}\right)\left(\operatorname{depth}(\mathrm{cm})^{-0.85}\right)
$$

The temperature corrected $\mathrm{K}_{\mathrm{O} 2}$ for temperature at each time measurement:

$$
K_{O 2(T i)}=K_{O 2\left(20^{\circ} \mathrm{C}\right)} * 1.0241^{\left(T i-20^{\circ} \mathrm{C}\right)}
$$

The reaeration flux:

$$
R F\left(m g O_{2} L^{-1} m^{-1}\right)=\left(K_{O 2(T i)} * D\right) / \text { time interval }(\mathrm{min})
$$

The night-time respiration rate:

$$
N R R\left(\mathrm{mg} \mathrm{O}_{2} L^{-1} \mathrm{~min}^{-1}\right)=\frac{\left(\Delta D O-K_{O 2(T i)} * D\right)}{\text { time interval }(\mathrm{min})}
$$

The average of all NRR:

$$
\text { Rnight }=\Sigma N R R\left(m g \mathrm{O}_{2} L^{-1} \mathrm{~min}^{-1}\right) / n
$$

The day-time respiration rate:

$$
\operatorname{DRR}\left(\mathrm{mg} \mathrm{O}_{2} L^{-1} \mathrm{~min}^{-1}\right)=R_{\text {night }} * 1.072^{\text {Ti-Tnight }}
$$

The GPP flux:

$$
G P P_{f l u x}\left(m g O_{2} L^{-1} \min ^{-1}\right)=\frac{\Delta D O-K_{O 2(T i)} * D}{\text { time }(\min )+R_{\text {night }} * 1.072^{\text {Ti-Tnight }}}
$$

Daily GPP:

$$
G P P\left(m g O_{2} L^{-1} d^{-1}\right)=\Sigma G P P_{\text {flux }} * \text { time }
$$

$\operatorname{GPP}\left(m g \mathrm{O}_{2} m^{-2} d^{-1}\right)=\operatorname{GPP}\left(m g O_{2} L^{-1} d^{-1}\right) * \operatorname{depth}_{(\text {mean })} * 1000$

Daily ecosystem respiration:

$$
E C\left(m g O_{2} L^{-1} d^{-1}\right)=\frac{\Sigma D R R+\Sigma N R R}{\text { time }}
$$

$E R\left(m g O_{2} m^{-2} d^{-1}\right)=E R\left(m g O_{2} L^{-1} d^{-1}\right) * \operatorname{depth}_{(\text {mean })} * 1000$

We tested for differences in environmental parameters, OM stocks and inputs, GPP and ER among seasons and streams using two-way ANOVA followed by Holm Sidak post hoc pairwise comparisons performed in SigmaPlot 14.0. We evaluated the correlation between environmental parameters, OM stocks and inputs, GPP, and ER using a principal component analysis performed in PRIMER 7.

\section{RESULTS}

\section{Environmental parameters}

The José and Mario streams are warm, welloxygenated, from slightly acid to slightly basic and with low electrical conductivity (Table 1$)$. The José stream had higher $\mathrm{pH}(F=63.2002, p<0.001)$, conductivity $(F=647.608, p<0.001)$ and water discharge $(F=7.481, p=0.026)$ than the Mario stream. Temperature $(F=2.313, p=0.167)$, dissolved oxygen $(F=1.488, p=0.257)$, turbidity $(F=1.203, p=0.305)$ and chlorophyll- $a(F=1.601$, $p=0.241)$ were not significantly different between streams. Nutrient concentrations were low (i.e., oligotrophic) and not significantly different between streams (Table $1, \mathrm{NH}_{4} F=2.130, p=0.183 ; \mathrm{NO}_{3}{ }^{-}$ $F=1.264, p=0.293$; DIN: $F=0.512, p=0.494$; TP $F=0.055, p=0.821)$. The substrate is coarse in both streams, composed mainly of sands (35 $44 \%$ ) and gravel-boulders (24 - $38 \%$ ). 
Table 1. Physical and chemical parameters (mean \pm s.d., $\mathrm{n}=18$ ) of the José and Mario streams. Parámetros fisicoquímicos (promedio \pm d.e., $n=18$ ) de los arroyos José y Mario.

\begin{tabular}{lcccc}
\hline \multirow{2}{*}{ Parameter } & \multicolumn{2}{c}{ José stream } & \multicolumn{2}{c}{ Mario stream } \\
& Rainy season & Dry season & Rainy season & Dry season \\
\hline Total lenght $(\mathrm{m})$ & \multicolumn{2}{c}{1321} & \multicolumn{2}{c}{3280} \\
Mean width $(\mathrm{m})$ & \multicolumn{2}{c}{$4.0 \pm 1.1$} & \multicolumn{2}{c}{$3.1 \pm 1.6$} \\
Mean depth $(\mathrm{m})$ & $0.40 \pm 0.25$ & $0.41 \pm 0.25$ & $0.30 \pm 0.23$ & $0.39 \pm 0.31$ \\
Water discharge $\left(\mathrm{m} / \mathrm{s}^{3}\right)$ & $0.29 \pm 0.03$ & $0.18 \pm 0.04$ & $0.16 \pm 0.15$ & $0.04 \pm 0.01$ \\
Temperature $\left({ }^{\circ} \mathrm{C}\right)$ & $22.2 \pm 0.6$ & $23.2 \pm 1.5$ & $25.5 \pm 0.7$ & $24.7 \pm 1.9$ \\
Dissolved oxygen $(\mathrm{mg} / \mathrm{L})$ & $7.5 \pm 0.7$ & $7.7 \pm 1.2$ & $7.1 \pm 0.6$ & $6.2 \pm 1.7$ \\
pH & $8.1 \pm 0.3$ & $7.9 \pm 0.1$ & $6.9 \pm 0.3$ & $6.5 \pm 0.2$ \\
Conductivity $(\mu \mathrm{S} / \mathrm{cm})$ & $959 \pm 8$ & $1069 \pm 96$ & $73 \pm 21$ & $63 \pm 23$ \\
Turbidity $(\mathrm{NTU})$ & $12 \pm 14$ & $3 \pm 12$ & $30 \pm 38$ & $18 \pm 38$ \\
Chlorophyll- $a(\mu \mathrm{g} / \mathrm{L})$ & $0.24 \pm 0.08$ & $0.25 \pm 0.12$ & $0.43 \pm 0.15$ & $0.24 \pm 0.17$ \\
Ammonium $\left(\mathrm{NH}{ }_{4}\right)(\mu \mathrm{Mol} / \mathrm{L})$ & $0.8 \pm 0.4$ & $1.3 \pm 1.0$ & $1.1 \pm 0.5$ & $3.2 \pm 1.9$ \\
Nitrate $\left(\mathrm{NO}_{3}{ }^{-}\right)(\mu \mathrm{Mol} / \mathrm{L})$ & $13.1 \pm 7.6$ & $11.8 \pm 6.0$ & $10.3 \pm 1.8$ & $8.1 \pm 3.5$ \\
Total inorganic dissolved N $(\mathrm{DIN})(\mu \mathrm{Mol} / \mathrm{L})$ & $14.6 \pm 7.5$ & $13.3 \pm 7.0$ & $11.7 \pm 1.8$ & $11.5 \pm 5.2$ \\
Total phosphorus $(\mathrm{TP})(\mu \mathrm{Mol} / \mathrm{L})$ & $1.5 \pm 0.6$ & $4.0 \pm 4.6$ & $1.4 \pm 0.1$ & $3.1 \pm 3.3$ \\
DIN:TP & 9.7 & 3.3 & 8.4 & 3.7 \\
\hline & & & & \\
\hline
\end{tabular}

Table 2. Abundance (mean \pm s.d.) of the organic matter stock and input and metabolism estimations in the José and Mario streams (DOM: dissolved organic matter, GPP: gross primary production, ER: ecosystem respiration). Abundancia (promedio \pm d.e.) de los diferentes almacenes y entradas de materia orgánica y estimaciones de metabolismo en los arroyos José y Mario (DOM: materia orgánica disuelta, GPP: producción primaria bruta, ER: respiración ecosistémica).

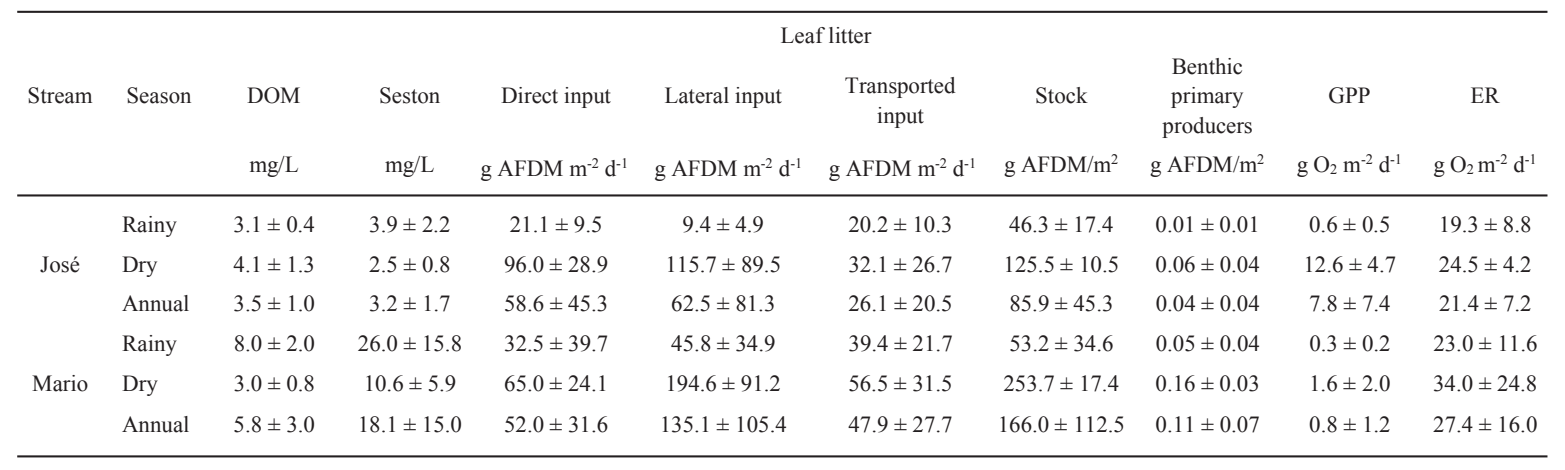

Water discharge $(F=9.771, p=0.014)$ and turbidity $(F=5.360, p=0.040)$ were higher in the rainy season than in the dry season in the streams. Temperature $(F=0.714, p=0.423)$, dissolved oxygen $(F=0.440, p=0.526), \mathrm{pH}(F=3.247$, $p=0.109)$, conductivity $(F=2.124, p=0.183)$, chlorophyll- $a(F=0.100, p=0.760)$ and nutrients did not significantly differ between seasons
$\mathrm{NH}_{4} F=3.394, p=0.103 ; \mathrm{NO}_{3}^{-} F=0.068$, $p=0.800 ; \mathrm{DIN}: F=0.009, p=0.925 ; \mathrm{TP} F=0.792$, $p=0.400)$.

\section{Organic matter}

Organic matter stock and input amply varied in both streams (Table 2, Fig. 3). DOM ranged be- 
tween 0.5 and $10.2 \mathrm{mg} / \mathrm{L}$, while seston ranged between 0.002 and $0.02 \mathrm{mg} / \mathrm{L}$. Leaf litter inputs ranged between 5.9 and $255.6 \mathrm{~g}^{\text {AFDM m}} \mathrm{m}^{-2} \mathrm{~d}^{-1}$ and were mainly represented by the lateral input. Leaf litter stock was the most abundant particulate organic matter stock, ranging between 20.4 and $357.8 \mathrm{~g} \mathrm{AFDM} / \mathrm{m}^{2}$, while benthic primary producers ranged between 0.01 and $0.19 \mathrm{~g}$ AFDM $/ \mathrm{m}^{2}$. Benthic primary producers were dominated by the green algae Cladophora, the diatoms Surirella, Girosigma, Navicula, Coconeis, Ulnaria, Pinnularia, Flagilaria, Gomphonema, Amphora, and Diploneis, and an undetermined Characeae.
DOM $(F=16.184, p=0.004)$, transported leaf litter $(F=7.709, p=0.024)$ and benthic primary producers $(F=14.748, p=0.005)$ were significantly higher in the Mario stream than in the José stream. Seston $(F=0.666, p=0.438)$ and leaf litter lateral input $(F=2.351, p=0.164)$, direct input $(F=0.506, p=0.497)$ and stock $(F=1.848, p=0.211)$ did not significantly differ between streams.

DOM was higher in the rainy season in the Mario stream but did not differ between seasons in the José stream (Season $F=15.899, p=0.004$, stream $x$ season $F=38.300, p<0.001$, HolmSidak for José $t=1.557, p=0.158)$. Similar-
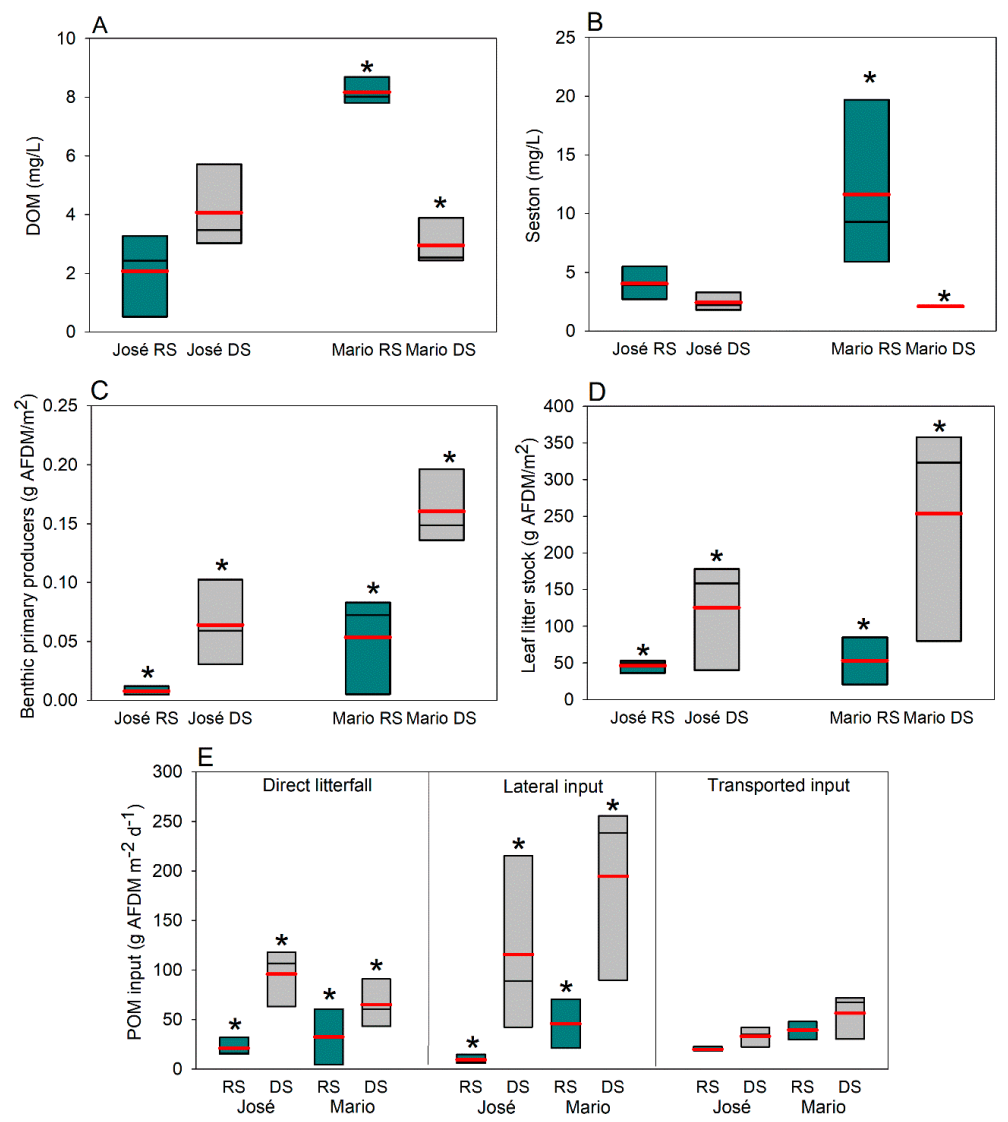

Figure 3. Seasonal variation (RS: rainy season, DS: dry season) of the different organic matter stocks and inputs in the José and Mario streams. A: DOM $(n=3)$, B: seston $(n=3)$, C: benthic primary producers $(n=6)$, D: leaf litter stocks $(n=6)$, E: leaf litter inputs $(\mathrm{n}=6)$ Mean: red lines, median: black lines. * indicates significant differences. Variación estacional (RS: temporada de lluvias, $D S$ : temporada de secas) de los diferentes almacenes y entradas de materia orgánica en los arroyos José y Mario. A: DOM ( $n=3$ ), B:seston ( $n=3)$, C: productores primarios bentónicos $(n=3)$, D: hojarasca almacenada $(n=6)$, E: aportes de hojarasca $(n=6)$. Promedio: líneas rojas, mediana: líneas negras). * indica diferencias significativas. 
ly, seston was higher in the rainy season in the Mario stream but did not differ between seasons in the José stream (Season $F=14.098, p=0.004$, stream $x$ season $F=25.697, p<0.001$, HolmSidak for José $t=0.452, p=0.293)$. Leaf litter direct input $(F=15.065, p=0.005)$, lateral input $(F=11.502, p=0.009)$, stock $(F=7.936$, $p=0.023)$ and benthic primary producers $(F=19.392, p=0.002)$ were higher in the dry than in the rainy season in both streams. Transported leaf litter $(F=3.875, p=0.085)$ did not differ between seasons in the streams.

\section{Stream metabolism}

GPP in the José stream ranged between 0.25 and $15.77 \mathrm{~g} \mathrm{O}_{2} \mathrm{~m}^{-2} \mathrm{~d}^{-1}$. In Mario, it ranged between 0.15 and $3.09 \mathrm{~g} \mathrm{O}_{2} \mathrm{~m}^{-2} \mathrm{~d}^{-1}$. It significantly differed between streams and seasons, but the interaction was significant (stream $x$ season $F=21.523$, $p=0.002$ ). GPP was significantly higher in the rainy season than in the dry season in José $(t=5.911$, $p<0.001)$, but it did not differ between seasons in Mario $(t=0.650, p=0.534)$. It was also significantly higher in José than in Mario only in the rainy season $(t=6.049, p<0.001$, Table 2$)$.

ER in José ranged between 9.69 and $27.53 \mathrm{~g}$ $\mathrm{O}_{2} \mathrm{~m}^{-2} \mathrm{~d}^{-1}$. In Mario, it ranged between 9.61 and $51.52 \mathrm{~g} \mathrm{O}_{2} \mathrm{~m}^{-2} \mathrm{~d}^{-1}$. ER did not differ between seasons or streams (stream $F=0.701, p=0.427$, season $F=4.042, p=0.079$, stream $x$ season $F=0.324, p=0.585$, Table 2).

The first two components of PCA explained $50.6 \%$ of the variation (Fig. 4). PC1 explained $33.7 \%$ and was positively correlated to leaf litter stock (0.321), lateral input (0.235) and benthic primary producers $(0.337)$, and negatively correlated to water discharge (-0.334). PC2 explained $16.9 \%$, was positively correlated to GPP $(0.284)$, and negatively correlated to DOM $(-0.353)$, direct litterfall (-0.321) and ER (-0.248).

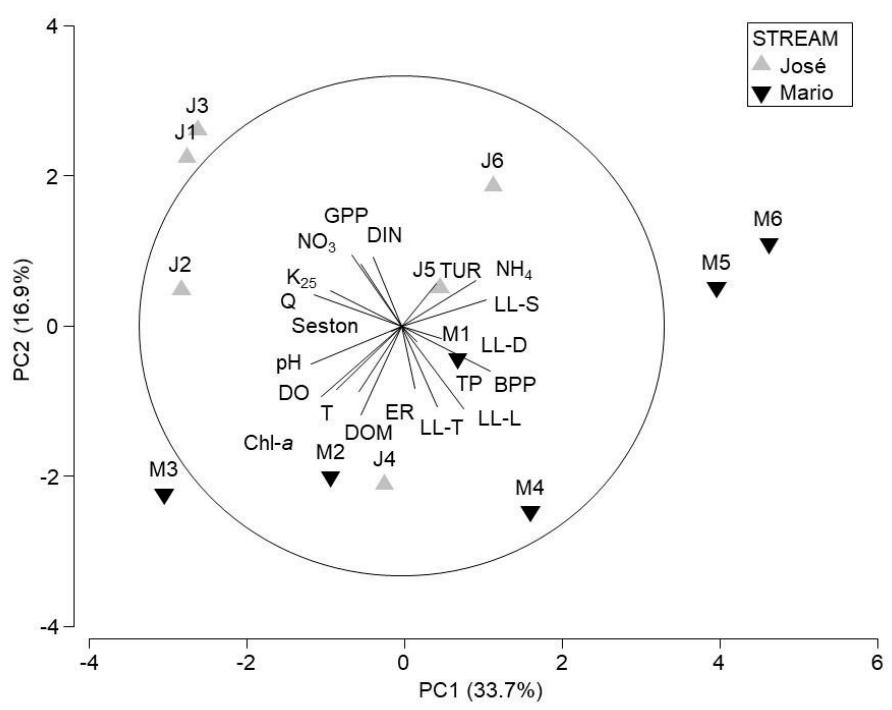

Figure 4. PCA between environmental parameters, organic matter stocks and inputs, and stream metabolism. Q: water discharge, T: temperature, DO: dissolved oxygen, $\mathrm{K}_{25}$ : conductivity, TUR: turbidity, Chl- $a$ : chlorophyll- $a, \mathrm{NH}_{4}$ : ammonium, $\mathrm{NO}_{3}$ : nitrate, DIN: total inorganic dissolved nitrogen, TP: total phosphorus, DOM: dissolved organic matter, BPP: benthic primary producers, LL-S: leaf litter stock, LL-D: direct litterfall, LL-L: leaf litter lateral input, LL-T: leaf litter transported input, GPP: gross primary production, ER: ecosystem respiration. PCA entre parámetros ambientales, almacenes y aportes de materia orgánica y metabolismo ecosistémico. Q: caudal, T: temperatura, DO: oxígeno disuelto, $\mathrm{K}_{25}$ : conductividad, TUR: turbidez, Chl-a: clorofila-a, $\mathrm{NH}_{4}:$ amonio, $\mathrm{NO}_{3}$ : nitrato, DIN: nitrógeno disuelto inorgánico total, TP: fósforo total, DOM: materia orgánica disuelta, BPP: productores primarios bentónicos, LL-S: almacén de hojarasca, LL-D: caída directa de hojarasca, LL-L: aporte lateral de hojarasca, LL-T: aporte transportado de hojarasca, GPP: producción primaria bruta, ER: respiración ecosistémica. 


\section{DISCUSSION}

\section{Organic matter variation}

The magnitude of organic matter input and stock measured in our study was low compared to other tropical low-order streams (e.g., Bambi et al., 2017; Dudgeon et al., 2010; García et al., 2016; Li \& Dudgeon, 2008; Mantel et al., 2004; Molinero, 2019; Tonin et al., 2017).

DOM and seston significantly increased in the Mario stream in the rainy season, as reported in temperate and tropical streams and rivers (Atkinson et al., 2009; Wiegner et al., 2009). On the contrary, DOM and seston did not differ between seasons in the José stream.

The abundance of benthic primary producers increased in the dry season in both streams negatively correlated to water discharge. Increased discharge in the rainy season imposes two adverse effects on benthic algae in tropical streams. Faster currents might flush algae out from the channel, particularly at the beginning of the rainy season (Bleich et al., 2015). Moreover, rainfall favors the riparian vegetation growth, which increases the shade above the channel and limits the benthic algae development (Bleich et al., 2015).

Leaf litter standing stocks in the José and Mario streams increased in the dry season negatively correlated to water discharge, as reported in other tropical streams (Bambi et al., 2017; Colón-Gaud et al., 2008; Molinero, 2019). In low order streams, in-stream retention decreases with flooding or increasing water discharge in the rainy season, even in zones with high litter inputs (Colón-Gaud et al., 2008). In Ecuadorian streams, at the beginning of the rainy season, high amounts of leaf litter were transported downstream due to a lack of instream retention structures (Molinero, 2019). Large wood debris in the José and Mario streams covered less than $10 \%$ of the channels; therefore, the scarcity of retention structures favored the downstream transport of leaf litter during the rainy season.

Direct litterfall and lateral input in the José and Mario streams also increased in the dry season, while transported input did not significantly differ between seasons. A litterfall peak in the dry season is typical in tropical forests (Benson \& Pearson, 1993; Colón-Gaud et al., 2008; Mohan Kumar \& Deepu, 1992; Molinero, 2019; Tonin et al., 2017; Wieder \& Wright, 1995), often as a consequence of water stress on terrestrial vegetation (Bambi et al., 2017; Tonin et al., 2017). Lateral transport increases in the dry season since dry leaves are more easily transported by wind (Tonin et al., 2017). Wind velocity increases in the dry season in the study region, which likely increases the transportation of dry leaves.

\section{Stream metabolism variation}

GPP and ER values in the José and Mario streams were within the range of values reported from other tropical streams (GPP: $0.1-16.2 \mathrm{~g} \mathrm{O}_{2} \mathrm{~m}^{-2} \mathrm{~d}-1$, ER: 0.6-42.1 $\mathrm{g} \mathrm{O}_{2} \mathrm{~m}^{-2} \mathrm{~d}-1$; Gücker et al., 2009; Bernot et al., 2010; Saltarelli et al., 2018). Moreover, ER values exceeded GPP values in each sampling date, suggesting heterotrophy in the streams.

GPP increased in the dry season in the José stream, while there were no statistically significant differences between seasons in the Mario stream. Nonetheless, there was no significant correlation between GPP and benthic macroalgae abundance, although they both increased in the dry season. Lower water discharge and lower turbidity likely favored microorganism activity (not measured) in the dry season, leading to higher GPP (Douglas et al., 2005; García et al., 2016; Townsend \& Douglas, 2014).

ER did not differ between seasons in either stream. The principal component explaining the ER variation explained a low percentage $(<20 \%)$ and included direct litterfall and DOM along with ER. In forested streams, leaf litter and DOC are the primary drivers contributing to the ER and decomposition process (Bernot et al., 2010; Saltarelli et al., 2018; Vannote et al., 1980). However, ER did not reflect the leaf litter increase in the dry season in both streams, nor the DOM increase in the rainy season in the Mario stream. This lack of correlation might be related to a) the leaf litter stock was highly abundant in both seasons and b) seasonal DOM changes were not significant enough to modify the stream metabolism. 


\section{Drivers of stream metabolism}

The organic matter stocks and inputs explained a low percentage of stream metabolism variation. The lack of such correlation could be related to the metabolic activity of the smallest standing stocks of organic matter, i.e., microorganisms, that tend to be the most metabolically active components (Gawne et al., 2007). Moreover, when most organic matter in a stream is of allochthonous origins, like in the José and Mario streams, metabolism does not usually correlate with autochthonous producer biomass, and GPP and ER are rather uncoupled (Ortiz-Zayas et al., 2005). In streams with uncoupled GPP and ER, distal factors, like land use, influence metabolism more strongly than organic matter (Bernot et al., 2010).

GPP and ER in José and Mario streams did not correlate with nutrient concentrations, which is most likely associated with the oligotrophic status of the streams. The oligotrophic status, in turn, plays a major role in limiting the primary producer biomass. Low dissolved N:P ratios indicate $\mathrm{N}$ is strongly limiting GPP (Cotner et al., 2006; Hamilton \& Lewis, 1990). The $\mathrm{N}: \mathrm{P}<8$ found in the José and Mario streams revealed that $\mathrm{N}$ plays a significant role in controlling the in-stream primary productivity (Redfield, 1958). In streams with strong nutrient limitation, GPP does not correlate with nutrient concentrations probably because any increased loading of nutrients is rapidly consumed (Cotner et al., 2006; Garcia et al., 2015; Townsend et al., 2011). In addition, in N-limited streams, other nutrients, like phosphorous, do not correlate with GPP because its role is likely masked by other factors (Bernot et al., 2010).

\section{CONCLUSION}

The José and Mario streams displayed a seasonal variation in organic matter stock and input. The organic matter timing and quantity correlated to tropical seasonality and its effect on stream hydrology. Although several factors likely influence organic matter inputs and in-stream retention, the seasonality defined by the rainfall pattern is probably the main driver of organic matter dynamics in tropical streams. On the contrary, stream metabolism was not explained by tropical seasonal- ity. Environmental parameters and organic matter stocks and inputs were not good predictors of stream metabolism. The high amount of leaf litter probably masked the role of primary producers on GPP, while its constant supply resulted in relatively constant ER values in both seasons. Nutrients were not good predictors of stream metabolism since they were at very low concentrations.

\section{ACKNOWLEDGMENTS}

We would like to thank to the "Programa de Posgrado en Ciencias del Mar y Limnología", UNAM and to the CONACYT grant for the first author. This research was financially supported by FORDECYT-CONACYT 273646 "Fortalecimiento de las capacidades científicas y tecnológicas para la gestión territorial sustentable de la Cuenca del Río Usumacinta y su Zona Marina de Influencia (CRUZMI), así como su adaptación ante el cambio climático" project, and PAPIIT IN216818 "Flujos de carbono, nutrientes y sedimentos en un sistema lótico tropical" project. We acknowledge Fermín S. Castillo-Sandoval for his technical support with the analysis of nutrients. M.Sc. Martha Leticia Gaytan Herrera and Dra. Estela Cuna Pérez helped with the diatoms' determination. We thank to the "Fundación Natura y Ecosistemas Mexicanos AC" and the staff of the "Chajul" biological station for the logistic support during the field work.

\section{REFERENCES}

Álvarez-Porebski, P., Hernandez Garciadiego, L., Gómez-Ruíz, H., \& Ramírez-Martínez, C. (2015). Calidad del agua en la subcuenca del río Lacantún. In J. Carabias, J. de La Maza, R. Cadena, \& (coordinadores) (Eds.), Conservación y desarrollo sustentable en la Selva Lacandona. 25 años de actividades y experiencias (pp. 261-274). Natura y Ecosistemas Mexicanos, A.C..

Arar, E. J. \& Collins G. B. (1997). Method 445.0 In Vitro determination of Chlorophyll $a$ and Pheophytin a in marine and freshwater algae by fluorescence. US Environmental Protection Agency, Washington D.C., USA.

Atkinson, C. L., Golladay, S. W., Opsahl, S. P., 
\& Covich, A. P. (2009). Stream discharge and floodplain connections affect seston quality and stable isotopic signatures in a coastal plain stream. Journal of the North American Benthological Society, 28(2), 360-370. DOI: 10.1899/08-102.1

Bambi, P., de Souza Rezende, R., Feio, M. J., Leite, G. F. M., Alvin, E., Quintão, J. M. B., Araújo, F., \& Gonçalves Júnior, J. F. (2017). Temporal and Spatial Patterns in Inputs and Stock of Organic Matter in Savannah Streams of Central Brazil. Ecosystems, 20(4), 757-768. DOI: $10.1007 / \mathrm{s} 10021-016-0058-\mathrm{Z}$

Benson, L. J., \& Pearson, R. G. (1993). Litter inputs to a tropical Australian rainforest stream. Australian Journal of Ecology, 18(4), 377-383. DOI: 10.1111/j.1442-9993.1993. tb00465.x

Benson, Lee J., \& Pearson, R. G. (2020). Dynamics of organic material and invertebrates in a tropical headwater stream. Hydrobiologia, 847(1), 121-136. DOI: 10.1007/s10750-01904076-1

Bernot, M. J., Sobota, D. J., Hall, R. O., Mulholland, P. J., Dodds, W. K., Webster, J. R., Tank, J. L., Ashkenas, L. R., Cooper, L. W., Dahm, C. N., Gregory, S. V., Grimm, N. B., Hamilton, S. K., Johnson, S. L., McDowell, W. H., Meyer, J. L., Peterson, B., Poole, G. C., Maurice Valett, H. M., ... Wilson, K. (2010). Inter-regional comparison of land-use effects on stream metabolism. Freshwater Biology, 55(9), 1874-1890. DOI: 10.1111/j.13652427.2010.02422.x

Bleich, M. E., Piedade, M. T. F., Mortati, A. F., \& André, T. (2015). Autochthonous primary production in southern Amazon headwater streams: Novel indicators of altered environmental integrity. Ecological Indicators, 53, 154-161. DOI: 10.1016/j.ecolind.2015.01.040

Carvalho, E., \& Uieda, V. (2010). Input of litter in deforested and forested areas of a tropical headstream. Brazilian Journal of Biology, 70(2), 283-288. DOI: 10.1590/s151969842010005000015

Colón-Gaud, C., Peterson, S., Whiles, M. R., Kilham, S. S., Lips, K. R., \& Pringle, C. M. (2008). Allochthonous litter inputs, organic matter standing stocks, and organic seston dynamics in upland Panamanian streams: Potential effects of larval amphibians on organic matter dynamics. Hydrobiologia, 603(1), 301-312. DOI: 10.1007/s10750-008-9294-3

Cotner, J. B., Montoya, J. V., Roelke, D. L., \& Winemiller, K. O. (2006). Seasonally variable riverine production in the Venezuelan llanos. Journal of the North American Benthological Society, 25(1), 171-184. DOI: 10.1899/0887-3593(2006)25[171:SVRPIT] 2.0.CO;2

Davies, P. M., Bunn S. E. \& Hamilton S. K. (2008). Primary production in tropical streams and rivers. In: D. Dudgeon (ed.). Tropical Stream Ecology. (pp 24-43). Elsevier Academic Press, London, UK.

Demars, B. O. L., Thompson, J., \& Manson, J. R. (2015). Stream metabolism and the open diel oxygen method: Principles, practice, and perspectives. Limnology and Oceanography: Methods, 13(7), 356-374. DOI: 10.1002/ lom 3.10030

Douglas, M. M., Bunn, S. E., \& Davies, P. M. (2005). River and wetland food webs in Australia's wet-dry tropics: General principles and implications for management. Marine and Freshwater Research, 56(3), 329-342. DOI: 10.1071/MF04084

Dudgeon, D., Cheung, F. K. W., \& Mantel, S. K. (2010). Foodweb structure in small streams: do we need different models for the tropics? Journal of the North American Benthological Society, 29(2), 395-412. DOI: 10.1899/09-058.1

Fuß, T., Behounek, B., Ulseth, A. J., \& Singer, G. A. (2017). Land use controls stream ecosystem metabolism by shifting dissolved organic matter and nutrient regimes. Freshwater Biology, 62(3), 582-599. DOI: 10.1111/fwb.12887

Garcia, E. (2004). Modificaciones al sistema de clasificación Köppen: México. Offset Larios, México D.F., México.

Garcia, E. A., Pettit, N. E., Warfe, D. M., Davies, P. M., Kyne, P. M., Novak, P., \& Douglas, M. M. (2015). Temporal variation in benthic primary production in streams of the Australian wet-dry tropics. Hydrobiologia, 760(1), 4355. DOI: 10.1007/s10750-015-2301-6

García, P., Novelo-Gutiérrez, R., Vázquez, G., \& Ramírez, A. (2016). Allochthonous vs. Au- 
tochthonous energy resources for aquatic insects in cloud forest streams, veracruz, Mexico. Hidrobiologica, 26(3), 483-496. DOI: 10.24275/uam/izt/dcbs/hidro/2016v26n3/ garcia

Gawne, B., Merrick, C., Williams, D. G., Rees, G., Oliver, R., Bowen, P. M., Treadwell, S., Beattie, G., Ellis, I., Frankenberg, J., \& Lorenz, Z. (2007). Patterns of primary and heterotrophic productivity in an arid lowland river. River Research and Applications, 23, 1070-1087. DOI: $10.1002 / \mathrm{rra}$

Grace, M., \& Imberger, S. (2006). Stream Metabolism : Performing \& Interpreting Measurements. New South Wales Department of Environmental Conservation Stream Metabolism Workshop May, 31, 204. DOI: 10.4296/ cwrj3101041

Gücker, B., BoËchat, I. G., \& Giani, A. (2009). Impacts of agricultural land use on ecosystem structure and whole-stream metabolism of tropical Cerrado streams. Freshwater Biology, 54(10), 2069-2085. DOI: 10.1111/j.13652427.2008.02069.x

Hamilton, S., \& Lewis, W. M. (1990). Basin morphology in relation to chemical and ecological characteristics of lakes on the Oricono River floodplain, Venezuela. Archiv Für Hydrobiologie, 119(4), 393-425.

Hutchens Jr, J. J., Wallace J. B. \& Grubaugh J. W. (2017). Transport and storage of fine particulate organic matter. In: F.R. Hauer \& G.A. Lamberti (ed.). Methods in stream ecology. (pp 37-53). Elsevier Academic Press, London, UK.

Kirkwood, D. S. (1994). San-Plus segmented flow analyzer and its applications. Seawater Analysis. Skalar, Amsterdam, Neetherlands.

Li, A. O. Y., \& Dudgeon, D. (2008). Food resources of shredders and other benthic macroinvertebrates in relation to shading conditions in tropical Hong Kong streams. Freshwater Biology, 53(10), 2011-2025. DOI: 10.1111/j.13652427.2008.02022.x

Mantel, S. K., Salas, M., \& Dudgeon, D. (2004). Foodweb structure in a tropical Asian forest stream. Journal of the North American Benthological Society, 23(4), 728-755. DOI: 10.1899/0887-3593(2004)023<0728:fsiata $>$ 2.0.co;2
Meli, P., Ruiz, L., \& Carabias, J. (2015). La vegetación Riparia. In: Conservación y desarrollo sustentable en la Selva Lacandona.

Minshall, G. W., Thomas, S. A., Newbold, J. D., Monaghan, M. T., \& Cushing, C. E. (2000). Physical factors influencing fine organic particle transport and deposition in streams. Journal of the North American Benthological Society, 19(1), 1-16. DOI: 10.2307/1468278

Mohan Kumar, B., \& Deepu, J. K. (1992). Litter production and decomposition dynamics in moist deciduous forests of the Western Ghats in Peninsular India. Forest Ecology and Management, 50(3-4), 181-201. DOI: 10.1016/0378-1127(92)90335-7

Molinero, J. (2019). Seasonality and composition of benthic coarse particulate organic matter in two coastal tropical streams with different land uses. Hydrobiologia, 838(1), 29-43. DOI: $10.1007 / \mathrm{s} 10750-019-03974-8$

Muñoz-Salinas, E., \& Castillo, M. (2013). Sediment and Water Discharge Assessment on Santiago and Pánuco Rivers (Central Mexico): The Importance of Topographic and Climatic Factors. Geografiska Annaler, Series A: Physical Geography, 95(2), 171-183. DOI: 10.1111/geoa.12007

Odum, H. T. (1956). Primary Production in Flowing Waters. Limnology and Oceanography, 1(2), 102-117. DOI: 10.4319/1o.1956.1.2.0102

Ortiz-Zayas, J. R., Lewis, W. M., Saunders, J. F., McCutchan, J. H., \& Scatena, F. N. (2005). Metabolism of a tropical rainforest stream. Journal of the North American Benthological Society, 24(4), 769-783. DOI: 10.1899/03094.1

Pozo, J. \& Elosegui A. (2008). El marco físico: la cuenca. In: A. Elosegui \& S. Sabater (ed.). Conceptos y técnicas en ecología fluvial. (pp 39-49). Fundación BBVA, Bilbao, España.

Pujo-Pay, M. \& Raimbault P. (1994). Improvement of the wet-oxidation procedure for simultaneous determination of particulate organic nitrogen and phosphorus collected on filters. Marine Ecology Progress Series, 105 (1), 203-207.

Redfield, A. C. (1958). The Biological Control of Chemical Factors in the Environment. American Scientist, 46(3), 205-221. 
Richardson, D. C., Kaplan, L. A., Newbold, J. D., \& Aufdenkampe, A. K. (2009). Temporal dynamics of seston: A recurring nighttime peak and seasonal shifts in composition in a stream ecosystem. Limnology and Oceanography, 54(1), 344-354. DOI: 10.4319/ 10.2009.54.1.0344

Rios Touma, B., Encalada, A. C., \& Prat Fornells, N. (2009). Leaf litter dynamics and its use by invertebrates in a high-altitude tropical andean stream. International Review of Hydrobiology, 94(4), 357-371. DOI: 10.1002/ iroh.200811161

Saavedra Guerrero, A., López López, D. M., \& Castellanos Fajardo, L. A. (2015). Apéndice 1. El medio físico de la cuenca media del río Usumacinta-México. In J. Carabias, J. de la Maza, R. Cadena, \& (coordinadores) (Eds.), Conservación y desarrollo sustentable de la Selva Lacandona (pp. 582-612). Natura y Ecosistemas Mexicanos, A.C.

Saltarelli, W. A., Dodds, W. K., Tromboni, F., Calijuri, M. D. C., Neres-Lima, V., Jordão, C. E., Palhares, J. C. P., \& Cunha, D. G. F. (2018). Variation of stream metabolism along a tropical environmental gradient. Journal of Limnology, 77(3), 359-371. DOI: 10.4081/ jlimnol.2018.1717

Seyler, P., Coynel A., Moreira-Turcq P., Etcheber H., Colas C., Orange D., Bricquet J.P., Laraque A., Guyot J.L., Olivry J.C. \& Meybeck M. (2005). Organic carbon transported by the Equatorial Rivers: Example of Congo-Zaire and Amazon Basins. In: E.J. Roose, R. Lal, C. Feller, B. Barthes \& B.A. Stewart (ed.). Soil erosion and carbon dynamics. (pp 255-274). CRC Press, Boca Raton, USA.

Staehr, P. A., Testa, J. M., Kemp, W. M., Cole, J. J., Sand-Jensen, K., \& Smith, S. V. (2012). The metabolism of aquatic ecosystems: History, applications, and future challenges. Aquatic Sciences, 74(1), 15-29. DOI: 10.1007/ s00027-011-0199-2

Strickland, J. H. D. \& Parsons T. R. (1972). A practical handbook of seawater analysis. Bulletin of the Fisheries Research Board of Canada Vol. 167.

Tank, J. L., Rosi-Marshall, E. J., Griffiths, N. A., Entrekin, S. A., \& Stephen, M. L. (2010). A re- view of allochthonous organic matter dynamics and metabolism in streams. Journal of the North American Benthological Society, 29(1), 118-146. DOI: 10.1899/08-170.1

Tonin, A. M., Gonçalves, J. F., Bambi, P., Couceiro, S. R. M., Feitoza, L. A. M., Fontana, L. E., Hamada, N., Hepp, L. U., Lezan-Kowalczuk, V. G., Leite, G. F. M., Lemes-Silva, A. L., Lisboa, L. K., Loureiro, R. C., Martins, R. T., Medeiros, A. O., Morais, P. B., Moretto, Y., Oliveria, P. C. A., Pereira, E. B., ... Boyero, L. (2017). Plant litter dynamics in the forest-stream interface: Precipitation is a major control across tropical biomes. Scientific Reports, 7(1), 1-14. DOI: 10.1038/s41598-01710576-8

Townsend, S. A., \& Douglas, M. M. (2014). Benthic Algal Resilience to Frequent Wet-Season Storm Flows in Low-Order Streams in the Australian Tropical Savanna. Freshwater Science, 33(4), 1030-1042. DOI: 10.1086/678516

Townsend, S. A., Webster, I. T., \& Schult, J. H. (2011). Metabolism in a groundwater-fed river system in the Australian wet/dry tropics: Tight coupling of photosynthesis and respiration. Journal of the North American Benthological Society, 30(3), 603-620. DOI: 10.1899/10066.1

Valderrama, J. C. (1981). The simultaneous analysis of total nitrogen and total phosphorus in natural waters. Marine Chemistry, 10 (2), 109-122.

Vannote, R. L., Minshall, G. W., Cummins, K. W., Sedell, J. R., \& Cushing, C. E. (1980). The River Continuum Concept. Canadian Journal of Fisheries and Aquatic Sciences, 37, 130137. DOI: $10.1139 / \mathrm{f} 80-017$

Wetzel, R. G. (2001). Limnology Lake and River Ecosystems (R. G. Wetzel (ed.); Third Edit). Elsevier Academic Press.

Wieder, R. K., \& Wright, S. J. (1995). Tropical Forest Litter Dynamics and Dry Season Irrigation on Barro Colorado Island, Panama. Ecology, 76(6), 1971-1979. DOI: 10.2307/1940727 Wiegner, T. N., Tubal, R. L., \& MacKenzie, R. A. (2009). Bioavailability and export of dissolved organic matter from a tropical river during base- and stormflow conditions. Limnology and Oceanography, 54(4), 1233-1242. DOI: $10.4319 / 10.2009 .54 .4 .1233$ 